\title{
(An Outline of) The Impact of Future Social and Technological Trends On the Dissemination of Census Bureau Information
}

\author{
by Donald L. Day'
}

\begin{abstract}
This study examines social and technological trends that may impact the dissemination of U.S. census information via the Depository Library Program in the Year 2000 and beyond.

The study looks beyond currently emerging systems to examine a limited list of future issues in technology, regulation, funding, access, and user demand. It examines information dissemination in the broad, societal context, rather than concentrating narrowly upon the means of delivery. Its main objectives are to pinpoint key issues, to stimulate an appreciation of the inextricable nature of information in postindustrial society, and to recommend policies and directions for further research.
\end{abstract}

Contact: Donald L. Day, 4-284 Center for Science and Technology, Syracuse University, Syracuse, NY 13244 4100 USA. Bitnet: D01DAYXX@SUVM.

\section{STUDY METHOD}

Elite interviewing was interspersed with a review of literature in the future studies field.

\section{KEY RESEARCH QUESTIONS}

The key research questions drafted from an analysis of the literature and during the interviewing process were as follows.

\section{TECHNOLOGY}

1. What will be the leading edge information technologies in the first decade of the next century?

2. When and to what degree will depository library materials (especially census data) be distributed via CDROM or other machine-readable media?

3. What technological developments will affect patrons' remote electronic access to depository libraries?

4. What software and data structures will be required for electronically disseminated census data, to facilitate rapid and effective searches and retrieval?

REGULATION
5. What will be the sponsorship and impact of standardization efforts to facilitate network access to federal government information?

6. To what extent will anti-trust concerns inhibit development of data integration protocols and telecommunications software necessary for widespread network access to federal government information?

7. How will the distribution of government information be controlled, under whose auspices and with what objectives?

8 . How will data integrity be maintained without impeding widespread electronic dissemination of information?

\section{FUNDING}

9. Which sponsors of information production, dissemination and use will support high technology access, under what conditions and with what goals?

10. What are the prospects that Congress will choose to privatize depository library distribution? What impact would that have upon the quality, quantity, availability and cost of Census Bureau information?

\section{ACCESS}

11. What will be the minimum skill levels required of users and depository librarians in accessing electronically disseminated information?

12. To what degree might user fees and other costs of accessing electronically disseminated information disenfranchise individuals?

\section{USER DEMAND}

I3. What impact will changes in work force composition and employment arrangements have upon the types of census information sought by users?

\section{OVERVIEW OF FUTURE TRENDS}

- Strong rise in "knowledge industries"

- Increase in non-English speakers

- Swelling ranks of citizens over 65 
- Spending will continue to shift toward service industries ( $88 \%$ of work force in 2000 )

- Job retraining programs for $4 \%$ of work force

- Seventy percent of U.S. homes may have computers in 2000

- People changing careers an average of every 10 years

- Ranks of the self-employed will grow at a faster rate than salaried workers

- More mid-career professionals will become entrepreneurs

- Do-it-yourself activities will be popular, because a 32-hour work week will create more leisure time and due to the high cost of services

- Massive increases in storage technology

- Inferred major policy issues

$>$ privacy

$>$ the part government plays in information dissemination

$>$ intellectual property rights

$>$ functional literacy

\section{KNOWLEDGE IN POSTINDUSTRIAL SOCIETY}

Social organization will be shaped by intellectual technology in postindustrial America in accordance with what is known as the "Knowledge Theory of Value".

Knowledge, even when it is sold, remains with the producer. It is a "collective good" - once it has been created, it is available to all. There is little incentive for any single person or enterprise to pay for the production of knowledge unless a proprietary advantage (such as a patent or copyright registration) can be obtained. Thus, government policy in regard to intellectual property and contractor marketing of publicly funded products will be key in the management of future information dissemination technology.

A reduction in incentives for individuals or companies to produce knowledge will cause the responsibility for and costs of satisfying information needs to fall to government. Whether information dissemination is "privatized" and in what manner may affect the availability of that information significantly.

\section{THE U.S. AS POSTINDUSTIRAL STATE}

The optimistic view

1. Centrality of theoretical knowledge as the basis of innovation.

2. Creation of new intellectual techniques to engineer solutions to economic (and even social) problems. 3. The spread of a (technical and professional) knowledge class.

4. The change from goods to human services.

5. A change in the character of work (people must leam to live with one another, since interaction among groups will be key).

6 . The employment of women in expanded human services.

7. Science as the societal standard bearer.

8. Political units comprised of either vertical organizations of individuals into scientific, technological, administrative, and cultural centers, or of institutions arrayed as economic, government, university, or social complexes.

9. Meritocracy (an emphasis on education and skill).

10. Scarcities of information and of time.

11. The economics of information.

The pessimistic view

New technology ...

1. Will be highly beneficial to some segments of society, but detrimental to others.

2 . Will have a positive impact primarily in the middleclass suburbs, with a negative impact in central cities. 3. Will not be properly understood and regulated until considerable damage has been done in major urban development.

4. Will reduce the economic viability of the central city by accelerating delocalization of business and commerce.

5. Will affect the service sector most, because its processes involve paper transactions that are particularly sensitive to technological substitution.

\section{FIVE MAJOR AREAS THAT MAY AFFECT} FUTURE DISSEMINATION

1. Technology

2. Regulation

3. Funding

4. Access

5. User Demand

- Technology

> Leading edge technologies

$>$ Machine-readable media

$>$ Remote electronic access

$>$ Software and data structures

- Regulation

$>$ Standardization

$>$ Anti-trust concerns

$>$ Control of distribution

$>$ Data integrity 


$$
\begin{aligned}
& \text { - Funding } \\
& >\text { Sponsors } \\
& >\text { Privatization } \\
& \text { - Access } \\
& >\text { Skill requirements } \\
& >\text { Disenfranchisement } \\
& \text { - User Demand } \\
& >\text { The aging population } \\
& >\text { Changes in the work force } \\
& >\text { Multilingual services }
\end{aligned}
$$

\section{KEY ISSUES}

Should future information dissemination be oriented toward individual users or toward businesses and institutions?

Should joint ventures with private industry be pursued as a means of funding future dissemination in the face of a shrinking federal budget?

What policies should be adopted regarding intellectual property rights in data analysis, access software development and copyright protection?

How and where should advanced indexing and retrieval software be procured for access to machine-readable data?

What role should be played in coordination of federal information dissemination policy to eliminate fragmentation of jurisdiction over media, content and formats?

How should demands for multilingual presentation be addressed?

To what extent is the Census Bureau liable for ensuring the integrity of data disseminated in machine-readable formats?

Would the Census Bureau be accountable for invasion of privacy or threats to defense or industry confidentiality that might result from the ability to manipulate data in machine-readable format (the "mosaic" issue)?

To what extent should the Census Bureau be involved in establishment of network protocol and human interface standards both within government and within industry?

How should responsibility and costs be divided for creation and maintenance of on-line access networks?

Should the Census Bureau abandon the depository library program in favor of altemative means of data dissemina- tion, or be a driving force in effecting a restructuring of the program in keeping with new information needs and dissemination technology?

What types of training should be provided for depository library staff to better enable them to deal with the challenges of new technology?

To what extent should collection acquisition, operating and other funds be diverted to the purchase of hardware and software to support the use of electronically disseminated information?

Should the Census Bureau decide upon the medium and content of information disseminated based upon extent and type of use research?

\section{CONCLUSION}

This study was fielded under the presumption that government will be required to continue providing public access to federal information as part of its commitment to maintaining the informed citizenry that is central to participatory democracy.

The nature of that access, however, is entwined in a host of social, economic and technology issues that must be addressed promptly if the pace of change is not to overwhelm policymakers as well as information intermediaries and users.

\section{REFERENCES}

Bell, D. (1978). The postindustrial economy. In J. Fowles, "Handbook of Futures Research". Westport, Conn.: Greenwood Press, 507-514.

Bezold, C. \& Olson, R. (1986). "The Information Millenium: Alternative Futures". Washington: Information Industry Assn.

Bortnick, J. \& Relyea, H. (1990, March 30). Interview at the Madison Building, Library of Congress, Washington, D.C.

Caddy, D. (1987). "Exploring America's Future". College Station, Tex.: Texas A\&M Univ. Press.

Cetron, M. (1988). Into the 21 st century. "The Futurist", 22:4, 29-40.

Clarke, A. (1978). Communications in the future. In J. Fowles, "Handbook of Futures Rescarch". Westport, Conn.: Greenwood Press, 637-652.

Comish, E. (1985). The library of the future. "The Futurist", 19:6, 2, 39. 
Diebold, J. (1985). New challenges for the information age. "The Futurist", 19:3, 68.

Eldredge, H. (1978). Urban Futures. In J. Fowles, "Handbook of Futures Research". Westport, Conn.: Greenwood Press, 617-636.

Federal information center program (1990). [A background paper.] (Available from the GSA Information Resources Management Service, Washington, DC 20405).

Freese, R. (1988). Optical disks become erasable. "IEEE Spectrum", 26:2, 41-45.

Government printing office improvement act of 1990. [HR 3849]. (Available from the Superintendent of Documents, Washington, DC).

Harm is averted by quick response to computer virus (1990). "Administrative Notes", 11 (April 13), 1. Newsletter of the Federal Depository Library Program.

Haub, C. \& von Cube, A. (1987). The United States Population Data Sheet (6th ed.). Washington, D.C.: Population Reference Bureau. In Marien, M. (Ed.), "Future Survey Annual" (Item Nr. 8369). Washington, D.C.: World Future Society.

Hemon, P. \& McClure, C. (1987). "Federal Information Policies in the 1980's: Conflicts and Issues". Norwood, N.J.: Ablex.

Lamm, R. (1985). "Megatraumas: America At the Year 2000". Boston: Houghton Mifflin.

Longman, P. (1988). The challenge of an aging society. "The Futurist", 23:5, 33-37.

Marshall, C. \& Rossman, G. (1989). "Designing Qualitative Research". Newbury Park, Calif.: Sage.

McGee, Milton (1990, March 30). Interview at the Adams Building, Library of Congress, Washington, D.C.

"The New American Boom". (1986). Kiplinger Washington Letter. Washington, D.C.: The Kiplinger Washington Editors, Inc.

“1988 Ten-Year Forecast". (1988). Menlo Park, Calif.: Institute For the Future.

Outlook '90 and beyond. (1989). "The Futurist",
$23: 6,53-60$.

Powell, Elizabeth (1990, February 16). Interview at the Hart Senate Office Building, Washington, D.C.

Tenner, E. The Revenge of Paper. "The New York Times", March 5, 1988, 27.

Weiner, E. \& Brown, A. (1989). Human factors: The gap between humans and machines. "The Futurist", 23:3, 9-11.

Weinstein, S. \& Shumate, P. (1989). Beyond the telephone: new ways to communicate. "The Futurist", 23:6, 8-12.

\section{AdDTtional Sources}

The following sources were identified in the literature search for this study, but are not referenced in the final report.

Comish, E. (Ed.) (1982). "Communications Tomorrow”. Bethesda, Md.: World Future Society.

Didsbury, H. (Ed.) (1982). "Communications and the Future". Bethesda, Md.: World Future Society.

Dowlin, K. (1984). "The Electronic Library". New York: Neal-Schuman.

Ferrarotti, F. (1986). "Five Scenarios for the Year 2000". New York: Greenwood Press.

Gorman, M. (Ed.) (1984). "Crossroads". (Proceedings of the First National Conference of the Library and Information Technology Assn., Sept. 1721, 1983, Baltimore, Md.). Chicago: American Library Assn.

Naisbitt, J. (1982). “Megatrends". New York: Warner Books.

Pasqualini, B. (Ed.) (1987). "Dollars and Sense: Implications of the New Online Technology for Managing the Library". Chicago: American Library Assn.

${ }^{1}$ Presented at the IASSIST 90 Conference held in Poughkeepsie, N.Y. May 30 - June 2, 1990.Donald L. Day, School of Information Studies, Syracuse University 